\title{
PENGARUH INDUKSI BAKTERI Pseudomonas aeruginosa TERHADAP HUMAN UMBILICAL VEIN ENDOTHELIAL CELLS (HUVECs) CULTURE
}

\section{THE INFLUENCE OF Pseudomonas aeruginosa INDUCTION TO THE HUMAN UMBILICAL VEIN ENDOTHELIAL CELLS (HUVECs) CULTURE}

\author{
Dwi Yuni Nur Hidayati \\ Fakultas Kedokteran,Universitas Brawijaya \\ Jl. Veteran, Malang 65145 \\ Telp. 0341-560491
}

\begin{abstract}
One of the cause of negative gram bacteria is Pseudomonas aeruginosa (Ps. aeruginosa). It continuing become sepsis on the first step of patogenesa happen sticking between aeruginosa with endhotel cell. This sticking is mediated by adhesi molecul which have characterize same with hemaglutin protein. The main study of this research is to know the profile of endothelial cell culture within induction of Ps. aeruginosa. The methods are Ps. aeruginosa (9064) which have been isolated then processes on TCBS Media and continued with isolation terracely. The profile of weight molecule protein obtained by SDS PAGE and then conducted electroelution. The test of hemaglutinin using eritrosit mencit. The receptor cell used is endhotel cell (HUVECs) culture. The result show that dosage of hemaglutin protein of Aeruginosa bring effect to profile of HUVECs culture determined by index adhesion of Ps. aeruginosa to HUVECs culture. We conclude that protein $38,19 \mathrm{kDa}$ give effect to profile of HUVECs culture in vitro.
\end{abstract}

Key words: Pseudomonas aeruginosa, adhesion protein, HUVECs

\section{Pendahuluan}

Tingginya kejadian dan problema penyakit infeksi yang biasanya dan selalu dikaitkan dengan keadaan negara berkembang atau higienis kurang, ternyata tidak seluruhnya benar. Di negara maju pun kini sangat direpotkan oleh penyakit infeksi. Di Amerika Serikat, kematian akibat sepsis tiap tahunnya mencapai 70.000 orang. Sekitar 50-60\% sepsis disebabkan oleh bakteriemi Gram-negatif. Penyebab Gram-negatif bakteriemia paling sering terjadi adalah famili Enterobacteriaceae dan Pseudomonaceae, yang terdiri dari Escherichia coli (35\%), Klebsiella, Enterobacter, Proteus (38\%), dan Pseudomonas aeruginosa (12\%) (Virella, 1997).

Pseudomonas aeruginosa (Ps. aeruginosa) adalah bakteri Gram negatif berbentuk batang, bergerak dengan flagela dan bersifat aerob. Bakteri ini banyak menginfeksi penderita di rumah sakit dengan predisposisi tertentu. Ps.aeruginosa mempunyai pili type IV yang berfungsi sebagai adhesin untuk mengikat sel host. Ps.aeruginosa dapat melakukan adhesi dan kolonisasi pada bermacam-macam type sel dari epitel sel buccal, paru, ginjal dan sel endothel (Comolli,1999).
Penemuan bahwa adhesi merupakan tahap awal proses infeksi pada kebanyakan bakteri, menunjukkan bahwa protein adhesin tersebut sangat mungkin digunakan sebagai komponen vaksin yang baik. Sebagai contoh Fim $\mathrm{H}$ vaccine yang sedang dikembangkan untuk mencegah infeksi saluran kemih yang disebabkan E.coli (Wizzeman,2000).

Pada kultur sel endotel secara in vitro yang disalutkan bakteri tertentu dimaksudkan untuk menjenuhi reseptor yang terlibat dari proses perlekatan diharapkan dapt menjelaskan sebagian patogenesa Ps. aeruginosa pada sel host dengan melihat profile perlekatannya (Wizzeman, 2000).

Penelitian ini mengarah pada profile kultur endotel yang diinduksi Ps. aeruginosa untuk menjelaskan faktor virulensi yang berpengaruh pada proses adhesi dengan sel endotel HUVECs sebagai tempat pelekatan bakteri Ps.aeruginosa yang diharapkan dapat memberikan informasi yang menarik untuk dikaji lebih lanjut.

\section{Materi dan Metode Penelitian}

Endotel HUVECs dikultur dalam media DMEM 199, glutamin, penicilin G, gentamicyne, $\mathrm{NaHCO}_{3}$, Penol red, $\mathrm{HCl} 1 \mathrm{~N}$ dan $\mathrm{NaOH}$ untuk mengukur $\mathrm{pH}$ hingga 7,4. Sediaan 
bakteri P. aeruginosa dalam kultur pada BHI (Brain Heart Infusion) dan media pada TCBS.

Isolat Ps. aeruginosa berasal dari koleksi sepuluh spesimen yang ada di Laboratorium Mikrobiologi RSSA Malang. Kemudian dilakukan identifikasi spesies dengan mengggunakan standard baku dari kit Microbact sistem.

\section{Metode Kultur Pseudomonas aeruginosa}

Bakteri yang digunakan adalah koleksi yang ada di Laboratorium Mikrobiologi Rumah sakit Saiful Anwar.Media yang digunakan menurut petunjuk Ehara (1992) yaitu TCG yang memperkaya pertumbuhan pili Ps. aeruginosa. Media ini mengandung $0,02 \%$ thioproline, $0,3 \%$ NaHCO3, $0,1 \%$ mono sodium 1glutamat, $1 \%$ bactotryptone, $0,2 \%$ yeast extract, $0,5 \% \mathrm{NaCl}, 2 \%$ bacto agar dan $1 \mathrm{mM}$ EGTA. Media agar dibuat dalam botol isinya $250 \mathrm{ml}$ secara miring sebanyak 50 botol, setiap botol berisi $50 \mathrm{ml}$ agar. Pseudomonas aeruginosa yang dipilih ditanam pada media media Brain Heart Infusion Broth (BHI), kemudian selama dikocok kuat selama 30 menit pada pemanas air suhu $37^{\circ} \mathrm{C}$. Kemudian suspensi bakteri sebanyak $10 \mathrm{ml}$ dimasukkan dalam setiap botol yang mengandung media TCG. Selanjutnya dilakukan pengeraman suhu $37^{\circ} \mathrm{C}$ selama $2 \mathrm{X}$ 24 jam.

Sodium Dodecyl Sulfate Polyacrylamid Gel Electrophoresis (SDS-PAGE)

Monitoring bobot molekul dikerjakan menggunakan SDS-PAGE metode Laemmli (1970). Sampel protein dipanaskan $100^{\circ} \mathrm{C}$ selama 5 menit dalam larutan penyangga yang mengandung $5 \mathrm{mM}$ Tris $\mathrm{HCl} \mathrm{pH} 6,8$, 2mercapto ethanol 5\%, w/v sodium dodecyl sulfate $2,5 \%$, v/v glyserol $10 \%$ dengan warna pelacak bromophenol blue. Dipilih 12,5\% mini slab gel dengan tracking gel4\%. Voltase yang digunakan $125 \mathrm{mV}$. Sebagai bahan warna adalah coomassie brilliant blue dan molekul standar sigma low range marker.

Isolasi dan pembuatan kultur sel endotel Semua bahan yang akan digunakan dihangatkan hingga $37^{\circ} \mathrm{C}$. Umbilikus dibersihkan dari jaringan dan clot yang ada dengan tissue. Masing-masing ujung umbilikus dipotong transversal sehingga terlihat dua arteri dan vena. Vena akan terlihat mempunyai dinding yang lebih tebal, lebih besar dan lentur. Masukkan kanul pada satu ujung vena ( klem) kemudian ikat dengan erat. Bersihkan vena dengan "PBS A" melalui kanul yang telah terpasang dengan menggunakan spuit $20 \mathrm{~cm}$. Setelah bersih, ikat ujung umbilikus yang tidak berkanul dengan ikatan yang kuat. Masukkan kolagenase ke dalam vena seperti pada cara 5 dan biarkan spuit masih terpasang pada kanul, kemudian umbilikus sidekap dengan tangan (agar mencapai $\sim 37^{\circ} \mathrm{C}$ ) selama 8 menit. Keluarkan kolagenase yang telah mengandung sel endotel dengan cara menyedot spuit yang masih terpasang. Dan larutan kolagenase tersebut ditaruh pada tabung sentrifuse yang steril. Ulangi cara seperti pemberian kolagenase (cara 6) tetapi dengan menggunakan PBS A sebanyak $8 \mathrm{ml}$. Kemudian sedot kembali seperti pada cara 7 dan taruhkan pada tabung sentrifuse yang telah berisi dengan kolagenase. Larutan yang telah mengandung sel endotel tersebut disentrifuse dengan kecepatan 1300 rpm selama 8 menit, ulangi sentrifuse satu kali lagi dengan menambahkan media sebanyak $2 \mathrm{ml}$ dalam tabung sentrifuse, putar $1300 \mathrm{rpm}$ selama 8 menit. Tuangkan supernatan, sedangkan pellet yang ada diresuspensi dengan medium kultur sebanyak $4 \mathrm{ml}$. Transfer larutan tersebut pada flask $25 \mathrm{~cm}^{2}$ dan masuk ke dalam inkubator $(5 \%$ $\mathrm{O}$ dan $95 \% \mathrm{CO}_{2}$ ). Pada hati berikutnya medium diambil dan dicuci dengan menggunakan serum free medium, kemudian kembali diisi medium kultur (4 ml). Setiap 2 hari sekali setengah dari medium diambil dan diganti dengan yang baru. Sel endotel akan berbentuk sebagai monolayer pada hari ke-3.

Metode Uji Adesi.

Uji adesi modifikasi Nagayama et al, 1995 dimana untuk tes adesi bakteri Ps.aeruginosa yang dibiakkan dalam lactose-broth pada suhu $37^{\circ} \mathrm{C}$. Biakan cair disentrifugasi $6.000 \mathrm{rpm}$ selama 10 menit pada suhu $4^{0} \mathrm{C}$. Endapan disuspensikan dengan PBS yang mengandung BSA $1 \%$ kandungan bakteri dibuat sekitar $10^{8} / \mathrm{ml}$ dengan menggunakan spektrofotometer dengan panjang gelombang 600nm. Suspensi bakteri diambil sebanyak $100 \mu \mathrm{l}$ dan dimasukkan dalam well yang didalamnya terdapat cover slip berisi endotel. Well dimasukkan dalam shaking inkubator goyangan 60 kali per menit, 30 menit, suhu $37^{\circ} \mathrm{C}$, kemudian cover slip dalam well dicuci 3 kali dengan PBS steril (calcium free). Cover slip diwarnai dengan kristal violet selama 1', bilas dengan air, cuci dengan lugol selama 1', bilas dengan air, cuci dengan aseton alkohol 96\% 1', bilas dengan air dan terakhir dicuci dengan safranin. Kemudian setelah dibilas bersih dengan air, cover slip dikering anginkan diatas tissue dan dilakukan pengamatan terhadap model adesi Ps. aeruginosa pada endotel dan model struktur endotel. Kemudian diamati 
dibawah mikroskop dengan pembesaran 200, 400, dan $1000 \mathrm{X}$, dan dilakukan perhitungan indeks adesi yaitu jumlah rata-rata bakteri yang menempel per 100 sel endotel.

\section{Hasil dan Pembahasan}

Gambaran dari kultur endotel normal dapat dilihat pada Gambar 1.

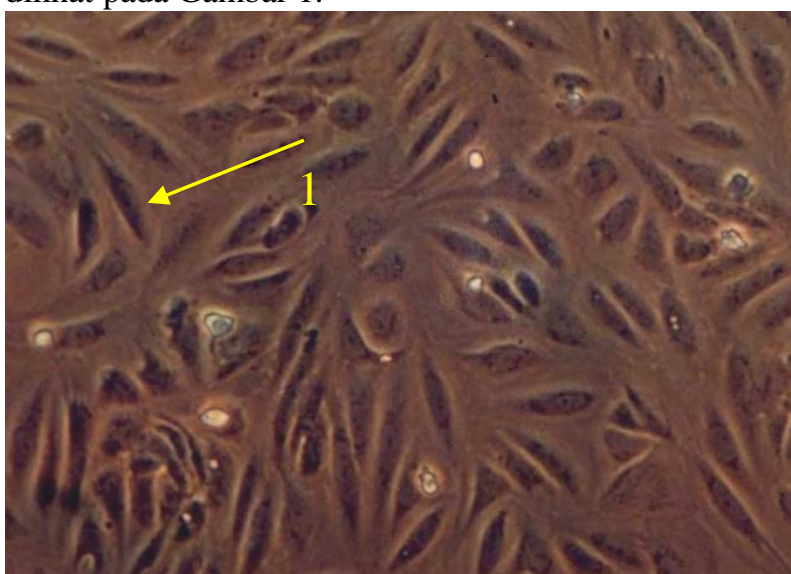

Gambar 1. Kultur sel endotel normal hari ke 5

Keterangan : 1. Sel endotel, bentuk pipih, permukaan mulus

Berdasarkan hasilisolasi protein dari sampel bakteri Ps.aeruginosa yang telah diisolasi dan dilakukan SDS-PAGE diperoleh Bobot molekul (BM) protein dengan hasil seperti pada Gambar 2.

Profil protein pada SDS-PAGE dari beberapa potongan pili Ps aeruginosa tampak pada gambaran potongan pili ketiga dengan gambaran pita protein yang menonjol. Gambaran pita protein yang paling menonjol yaitu $57,17 \mathrm{kDa} ; 38,19 \mathrm{kDa}$ dan $32,1 \mathrm{kDa}$. Gambaran ketiga protein yang menonjol tersebut dipotong untuk dikoleksi, selanjutnya dilakukan pemurnian dengan elektroelusi sehingga didapatkan protein larutan.

Uji Adesi (Metode Nagayama)

Hasil Uji adesi Ps.aeruginosa pada sel endotel (HUVECs) tampak seperti pada Gambar 3.

Berdasarkan hasil analisis varian satu jalur tampak bahwa dosis pengenceran protein Ps. aeruginosa berpengaruh sangat nyata terhadap indeks adhesi Ps.aeruginosa pada sel endotel (HUVECs) dengan signifikasi $\mathrm{F}$ hitung $(\mathrm{p})=$ 0,00 dan tingkat kepercayaan $95 \%$.

Perhitungan Indeks adesi pada tabel diatas

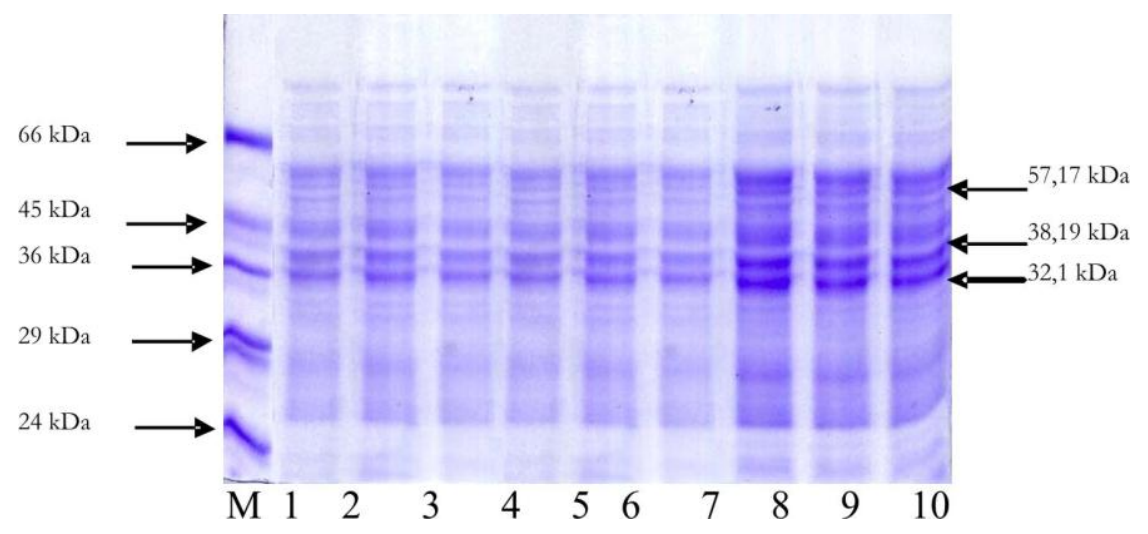

Gambar 2. Hasil SDS- PAGE Protein Ps. aeruginosa

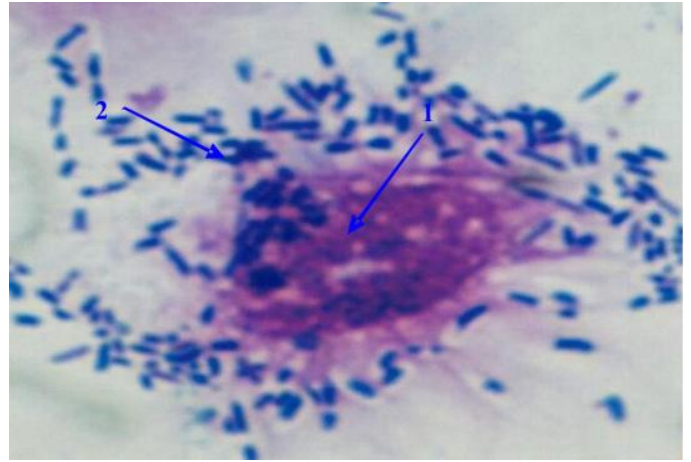

Gambar 3. Gambaran Adesi bakteri Pseudomonas aeruginosa pada sel endotel dengan pembesaran 1000x dengan Perlakuan Kontrol, Sediaan diwarnai Giemsa

Keterangan : 1. sel endotel (HUVECs), 2. Bakteri (Ps. aeruginosa) 


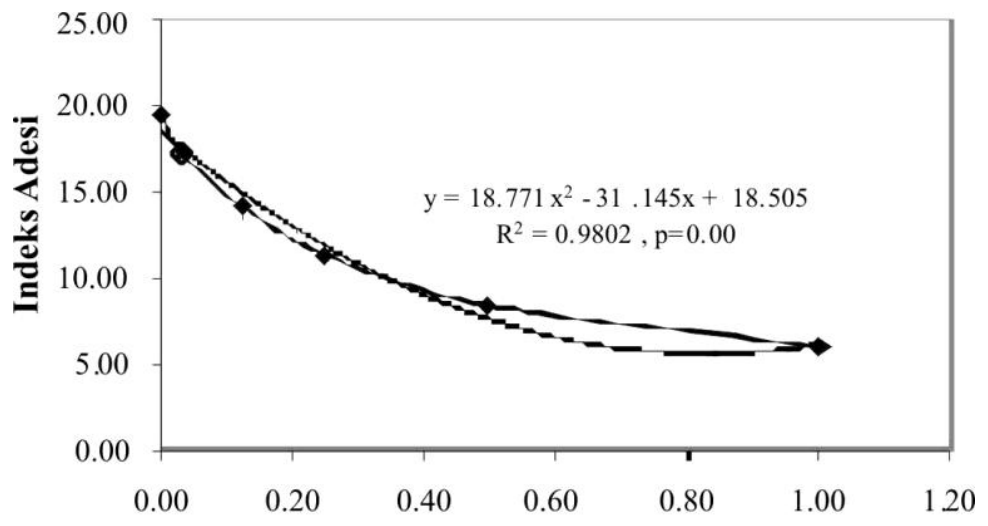

Konsentrasi Protein Hemaglutinin (uL)

Gambar 4. Scatter plot yang menunjukkan hubungan antara indeks adhesi Ps.aeruginosa dan konsentrasi protein Ps. aeruginosa $38,19 \mathrm{kDa}$

menunjukkan kecenderungan semakin tinggi protein hemagglutinin yang disalutkan, maka semakin sedikit bakteri yangmelekat pada sel endotel ( HUVECs), seperti pada Gambar 4.

Beberapa isolat Ps. aeruginosa yang diperoleh dari RSSA Malang ternyata setelah dilakukan uji hemaglutinin dengan menggunakan eritrosit mencit menunjukkan bahwa isolat Ps 9064 menunjukkan titer tertinggi pada pengenceran 0,0625 atau $1: 64$. Hasil fraksinasi protein $P s$ aeruginosa yang telah dilakukan dengan elektroforesis SDS Page untuk menentukan bobot molekul $57,17 \mathrm{kDa}$; $38,19 \mathrm{kDa} ; 32 \mathrm{kDa}$. Bobot molekul tersebut selanjutnya dielektroelusi untuk mendapatkan protein larutan yang kemudian dilanjutkan dengan uji hemaglutinasi. Pada saat interaksi dengan lingkungan ekstraseluler, bakteri gram negatif menggunakan faktor virulrensi termasuk toksin ekstraseluler, pili, curli, autotransporter, dan crystalin S-layers (Stathopoulos et al, 2000). Hal ini membuktikan bahwa Ps.aeruginosa mempunyai protein dengan berat $38,19 \mathrm{kDa}$ yang mampu memberikan pengaruh nyata terhadap profile perlekatan Ps. aeruginosa pada sel endotel HUVECs.

Adesi Ps. aeruginosa pada sel endotel HUVECs diantaranya ditentukan oleh faktor viruleni berupa pili. Penelitian lain menyebutkan bahwa bahwa Ps.aeruginosa juga mengaktivasi sel Mast manusia untuk menginduksi migrasi neutrophil transendothelial melalui sel $\mathrm{M}$ yang berasal dari IL-1alfa dan beta 1 (Jun et al., 2002). Pada sel endothel HUVECs apakah mekanisme adhesi ini juga dibutuhkan $P s$. aeruginosa untuk menginfeksi endothel, masih diperlukan penelitian lebih jauh lagi. Diduga bahwa adhesi Ps. aeruginosa terhadap endothel ditentukan oleh sekresi protein dengan general secretory pathway (GSP) yang merupakan dua bagian proses yang membutuhkan Sec translocase didalam inner membrane dan suatu substrat pemisah-sekresi spesifik apparatus selama sekresi menyeberangi outer membran. Salah satunya yang termasuk dalam GSP ini sebagai faktor virulensi untuk berinteraksi dan komunikasi dengan host adalah pili (Stathopoulos et al., 2000 dan Salyers, 1994).

Comer et al (2002) menjelaskan bahwa Ps. aeruginosa strain 1244 mempunyai pilin glycan yang berikatan secara kovalen terhadap residu serine. Hasil sequensing N-terminal dari fraksi pilin dihasilkan dari perlakuan endopeptidase dan diidentifikasi dengan reaksi monoklonal antibodi spesifik glycan yang terindikasi bahwa glycan ada diantara residu 75 dan terminus pilin karboksil. Bagian karboksilproksimal pada pilin disulfida loop, yang di ukur pada pilin glycan, merupakan epitop sel B linear utama, ini sebagai epitop peptida.

Hasil penelitian menunjukkan bahwa bobot molekul potongan pili ketiga adalah 38,19 kDa. Seperti dijelaskan oleh peneliti terdahulu bahwa pili Ps.aeruginosa merupakan pili sub unit monomerik akan tetapi bobot molekulnya adalah $15 \mathrm{kDa}-17 \mathrm{kDa}$, setelah ditentukan ternyata gene penyandinya adalah PilO. Diduga bahwa dari penelitian bobot molekul 38,19 kDa merupakan bobot molekul sub unit monomerik dengan jenis gene penyandi yang berbeda, sehingga untuk menentukan apakah bobot molekul tersebut merupakan monomer atau dimer sehinggan 
diperlukan penelitian lebih lanjut tentang jenis protein dan analisis gene penyandi protein $P S$. aeruginosa.

Castric et.al (2001) juga menjelaskan bahwa pili Ps. Aeruginosa merupakan pili somatik, filament protein yang meluas seperti benang dari satu atau kedua sel poles, yang merupakan faktor virulensi utama, memicu adherensi pada sel host dan proses invasi pada sel host. Berat molekul protein pili ini berkisar antara $16 \mathrm{kDa}$. Bentuk mature dari protein ini dihasilkan oleh pergerakan dari suatu sixresidue leader sequense sebuah proses yang diatur oleh metilasi pada nascent aminoterminal phenylalanine. Determinasi proses ini tergantung jenis gene penyadi pilO, yaitu sebuah gene yang terltakpada bagian operon yang juga mengandung pilin struktural gene pilA.. Bobot molekul kisaran $16 \mathrm{kDa}$ diketahui sebagai bobot molekul penentu patogen opportunistik pada bakteri gram negatif Ps.aeruginosa. Berdasarkan kajian literatur tersebut perlu ditentukan apakah bobot molekul protein dari hasil penelitian potongan pili ketiga $38,19 \mathrm{kDa}$ isolat Ps 9064 juga merupakan patogen oppurtunistik terhadap sel host khususnya sel endotel HUVECs.

Mekanisme invasi Ps. aeruginosa whole cell pada sel endotel HUVECs normal berdasarkan hasil penelitian menunjukkan bahwa struktur morfologi sel endotel kultur yang dengan pewarnaan wright dan pengamatan dengan mikroskop merk Nikon menunjukkan bentuk sel pipih, dengan struktur sitoplasma dan inti sel masih jelas, dan secara morfologis belum menunjukkan adanya perubahan morfologis secara nyata.

Gambaran adesi bakteri Ps. aeruginosa menunjukkan pola aggregat dan ada pula yang berpola diffuse atau menyebar pada permukaan sel endotel. Kultur sel endotel yang diperlakukan dengan adesi Ps. aeruginosa dan disalut dengan protein pili hemaglutinin pada potongan pili ketiga dengan bobot molekul $38,19 \mathrm{kDa}$ dengan berbagai pengenceran dosis menunjukkan bahwa semakin besar dosis protein hemaglutinin yang disalut pada sel endotel kultur menunjukkan adanya tingkat penghambatan adesi yang semakin besar, sehingga semakin besar pengenceran yang diberikan memberikan gambaran adesi yang jauh lebih besar dibandingkan dosis pemberian protein hemaglutinin tanpa pengenceran. Berdasarkan scatter plot dengan perlakuan protein hemaglutinin Ps. aeruginosa menunjukkan bahwa semakin besar pengenceran maka adesi bakteri tersebut menunjukkan peningkatan secara signifikan dengan nilai regresi $(\mathrm{r})=0,98$ dan $p$ value $=$ 0,00 . Hal ini diduga bahwa berdasarkan hasil regresi menggambarkan bahwa terdapat hubungan yang signifikan antara protein dengan bobot molekul 38,19 $\mathrm{kDa}$ dan adesi Ps. aeruginosa pada sel endotel kultur normal.

\section{Kesimpulan}

Protein bakteri Ps. aeruginosa 9064 dengan bobot molekul 38,19 kDa, yang merupakan protein adesi setelah protein tersebut disalutkan pada sel endotel (HUVECs) memberikan profile adesi pada sel endotel HUVECs.

\section{Daftar Pustaka}

Castric Peter, Cassels Frederick J.,Carlson Russel W, 2001, Sructural Charcterization of the Pseudomonas aeruginosa 1244 Pilin Glycan, Journal of Biological Chemistry, 270 ( 28) p 26479 - 26485

Comer Jason E,Marshal Mark A, Blanch Vincent J , Deal Carolyn D., 2002, Identifification of the Pseudomonas aeruginosa 1244 Pilin glycosylation Site, Infection and Immunity, 70 (6) p $2837-2845$

Comolli Janes C., Waite Leslie L., Mostov Keith E., Engel Joanne N., 1999, Pili Bending to Asialo - GM 1 on Epithelial Cells Can Mediate Cytotoxicity or Bacterial Internalisation by Pseudomonas aeruginosa, Infection and Imunity 67 (7) p $3207-3214$

Jun Lin-Tong, Garduno Rafael, Boudreau Robert T.M., Issekutz Andrew C., 2002, Pseudomonas aeruginosa Activates Human Mast Cells to Induce Neutrophil Transendothelial Migration Via Mast Cell-Derived IL $-1 \alpha$ and $\beta^{1}$, Journal Immunology, 169: 4522 -4530

Nagayama, K., Oguchi,T., Arita, M., Honda,T.,1995, Purification and Characterization of A Cell Associated Haemagglutinin of Vibrio parahaemolyticus, Infec.and Immun 63 (5): 1987 - 1992

Salyers Abigail A., Whitt Dixie D., 1994. Bacterial Pathogenesis. Washington DC: ASM Press, p. $31-35 ; 262$

Stathopoulos Christos, Hendrixson David R. Thanassi David G., Hultgreen Scott J.,2000, Secretion of Virulence determinants by the general secretory pathway in Gram - negative pathogens : an evolving story, Microbes and infection,2, p 1061 - 1072 
Virella Gabriel, 1997. Gram - negative Rods III : Opportunistic and Zoonotic Bacteri ; Microbiology and infectious disease 3 rd edition, Philadelpia : Williams \& Willins awaverly Company,p.159 162
Wizzemann, T.M., Adamoum J.E., and Langermann, S., 1999, Adhesins as Targets for Vaccine Development, Centers for Disease Control and Prevevtion, USA, p.1-5 